\title{
Peat Deposits and Thick-billed Murre Colonies in Hudson Strait and Northern Hudson Bay: Clues to Post-Glacial Colonization of the Area by Seabirds
}

\author{
ANTHONY J. GASTON ${ }^{1}$ and GARRY DONALDSON ${ }^{2}$
}

(Received 13 April 1995; accepted in revised form 5 July 1995)

\begin{abstract}
Deposits of peat moss are found in association with several major seabird colonies in the area of Hudson Strait and northern Hudson Bay. Because such deposits are absent from similar ground away from seabird colonies, they seem to have developed as a result of manuring by the birds. Consequently dates for the base of the peat provide minimum dates for the establishment of the bird colonies. Dates obtained at three colonies suggest that they were established 1500-3800 years ago, well after the opening up of Hudson Strait. The colony at Akpatok Island, in Ungava Bay, was established earlier than the two colonies farther west, at Digges and Coats Islands, which accords with the idea that colonization of the region took place from the Atlantic.
\end{abstract}

Key words: thick-billed murre, Uria lomvia, colony age, Hudson Strait, peat formation

RÉSUMÉ. On trouve des dépôts de mousse de tourbe associés à plusieurs grandes colonies d' oiseaux marins dans la zone du détroit d'Hudson et la partie septentrionale de la baie d'Hudson. Vu que de tels dépôts sont absents de terrains similaires éloignés des colonies d'oiseaux marins, il semble que leur formation soit due aux déjections des oiseaux. Les âges donnés pour la base de la tourbe fournissent donc les âges minimaux pour l'établissement des colonies d'oiseaux. Les âges obtenus pour trois colonies suggèrent que celles-ci ont été établies il y a de 1500 à 3800 ans, bien après l'ouverture du détroit d'Hudson. La colonie située sur l'île Akpatok, dans la baie d'Ungava, a été établie plus tôt que les deux colonies plus à l'ouest, dans l'île Digges et l'île Coats, ce qui s'accorde avec l'idée que la colonisation de la région s'est faite depuis l'Atlantique.

Mots clés: marmette de Brunnich, Uria lomvia, âge de la colonie, détroit d'Hudson, formation de la tourbe

Traduit pour la revue Arctic par Nésida Loyer.

\section{INTRODUCTION}

Seabird breeding colonies, with their accumulation of excreta, discarded food remains and dead chicks, are a source of intense local nutrient enrichment, sometimes leading to the establishment of distinctive vegetation communities or to enhanced growth of local plants (Gillham, 1956; Smith, 1978; Iason et al., 1986; Delarue, 1988; Stempniewicz, 1990). In the Arctic, where nutrient availability in soils is generally low and where the rate of volatilization of ammonia is also low (Mizutani et al., 1991a), manuring by seabirds can be a major factor in determining local vegetation characteristics and production. The nitrogen enrichment thus created can leave a recognizable signature in remnant soils long after the birds have ceased to breed at the site (Moors et al., 1988; Mizutani et al., 1991b).

The formation of localized patches of peat adjacent to major seabird colonies in the eastern Canadian Arctic has been noted previously (Gaston et al., 1985). Such peat deposits are found near all thick-billed murre (Uria lomvia) colonies in the Hudson Strait and northern Hudson Bay region: they form on areas adjacent to the tops of the vertical cliffs on which the birds breed. These cliffs range in altitude from $80-300 \mathrm{~m}$ a.s.1.
On level or moderately sloping ground, the areas of peat formation are characterized by a very uniform vegetation, dominated by the moss Dicranum groenlandicum. On steeper slopes, and on ledges on the cliffs themselves, grasses tend to dominate the flora, especially Poa arctica and Alopecurus alpinus, and the scurvy grass Cochlearia officinalis. The extent of peat formation varies with topography and moisture, but the peat usually terminates inland from $0.2 \mathrm{~km}$ to $1 \mathrm{~km}$ from the cliff edge or laterally along the cliff edge within a few hundred metres of the colony boundary.

Deposits of moss peat, especially those composed of Dicranum, are unusual on the rocky coasts adjacent to murre colonies or on the uplands which form their hinterland, except in areas of poor drainage (Polunin, 1932; our observations). Together with the occurrence of peat adjacent to the colonies, even on well-drained slopes, this distribution suggests that the presence of seabirds is essential for the formation of such peat deposits. Using this assumption, we can estimate a minimum age for the foundation of the colonies from the age of peat taken from the base of the deposits. In this paper, we describe peat deposits found adjacent to thick-billed murre colonies at Coats, East Digges and Akpatok Islands and present information on the minimum ages of these colonies, based on radiocarbon dating of basal peat samples.

\footnotetext{
${ }^{1}$ Canadian Wildlife Service, National Wildlife Research Centre, 100 Gamelin Blvd., Hull, Quebec K1A 0H3, Canada

${ }^{2}$ Department of Biology, University of Ottawa, Ottawa, Ontario K1N 6N5, Canada

(C) The Arctic Institute of North America
} 


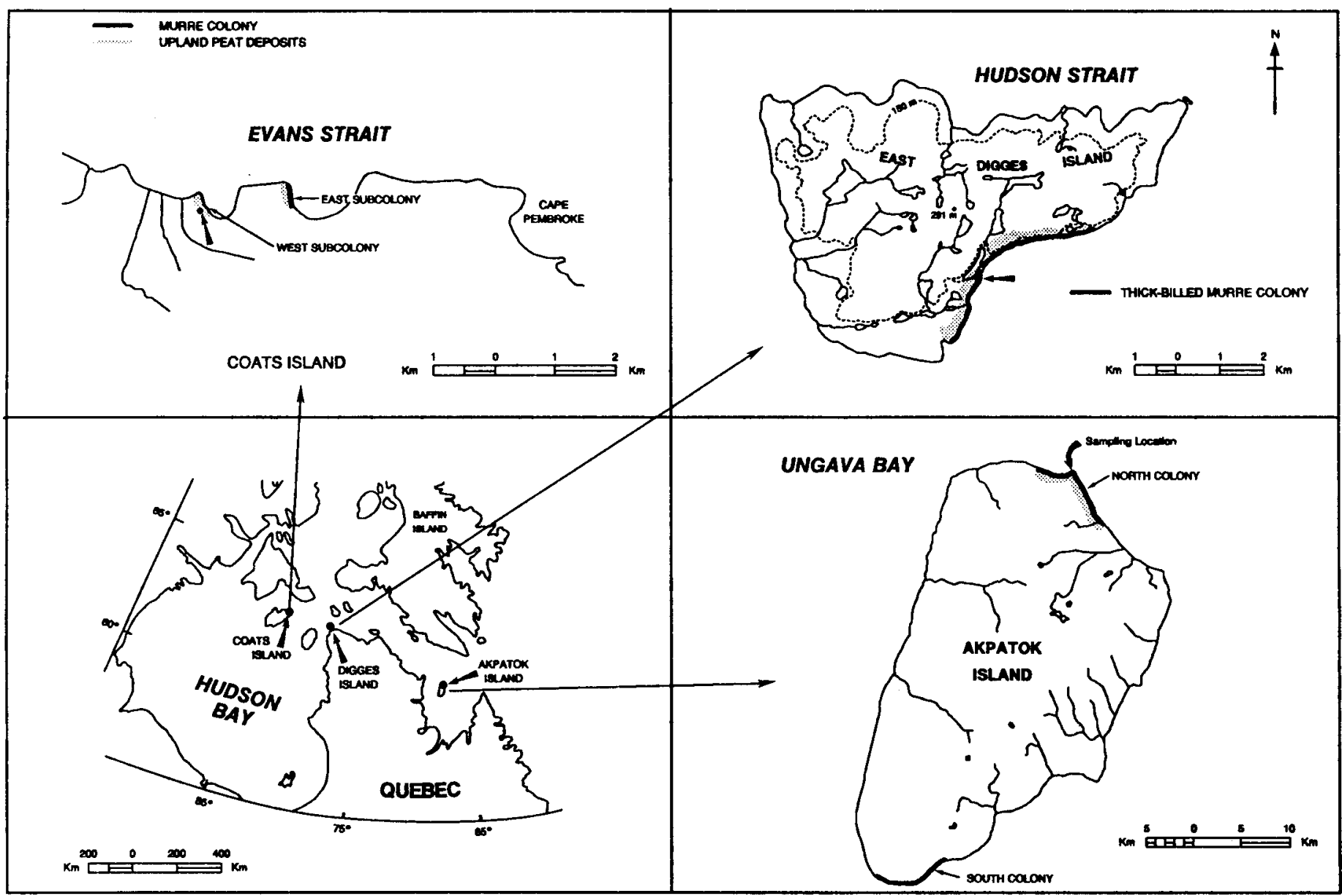

FIG. 1. The location of colonies visited and sampling sites.

\section{STUDY AREA AND METHODS}

The thick-billed murre colonies investigated (Fig. 1) have been described by the following authors: Akpatok Island $\left(60^{\circ} 35^{\prime} \mathrm{N}, 68^{\circ} 00^{\prime} \mathrm{W}\right)$ by Chapdelaine et al. (1986); East Digges Island $\left(62^{\circ} 33^{\prime} \mathrm{N}, 77^{\circ} 50^{\prime} \mathrm{W}\right)$ by Gaston et al. (1985) and Coats Island $\left(62^{\circ} 50^{\prime} \mathrm{N}, 82^{\circ} 00^{\prime} \mathrm{W}\right)$ by Gaston et al. $(1987,1993)$. All are situated on near-vertical cliffs that range in height from 50-80 $\mathrm{m}$ at Coats Island to 200-270 $\mathrm{m}$ at Akpatok Island. The cliffs are composed of Precambrian metamorphic rock at Digges and Coats Islands (Schau, 1991) and of horizontally bedded Palaeozoic limestones at Akpatok Island (Hentzel, 1993). In all cases, peat deposits were found within $100 \mathrm{~m}$ of the cliff edge, supporting a vegetation that comprises mainly Dicranum groenlandicum Brid. (identification confirmed by R.R. Ireland, pers. comm. 1993), with associated bakeapple Rubus chamaemorus and, at East Digges Island, cotton grass Eriophorum angustifolium and E. triste. Sampling sites were selected in the most level areas available, to minimize the risk that erosion through soil creep had removed the earliest peat laid down. The positions of sampling sites at Coats and East Digges Islands, in relation to the seabird cliffs, are shown in Figures 2 and 3.

Sampling was carried out at Digges Island in 1992, at Coats Island in 1992 and 1993, and at Akpatok Island
(North colony, Chapdelaine et al., 1986) in 1993. Samples of peat for radiocarbon dating were obtained at Digges and Coats Islands by excavating the peat as far as possible (at Digges to bedrock, at Coats to a point where continual flooding prevented further progress). As the peat was frozen below $10 \mathrm{~cm}$ from the surface, the excavation had to be performed with an axe. Samples of approximately $250 \mathrm{~g}$ (wet) each were shaved from the lowest peat levels reached: at Digges this was $0.7 \mathrm{~m}$ and at Coats $1.3 \mathrm{~m}$ vertically below the surface. At Akpatok Island, the dating sample was obtained from the base of the peat, where it was actively eroding at the cliff edge, by digging back horizontally to where the peat was in contact with bedrock. This sample was found at $2.0 \mathrm{~m}$ below the surface of the peat. All dating samples were air-dried below $25^{\circ} \mathrm{C}$. At Coats Island, additional samples of about $10 \mathrm{~g}$ wet weight were obtained for pollen analysis at $10 \mathrm{~cm}$ intervals throughout the section. These were preserved frozen.

Radiocarbon dating was carried out by the Radiocarbon Dating Laboratory of the Geological Survey of Canada on dry weight samples of $11 \mathrm{~g}$ (Akpatok), $8 \mathrm{~g}$ (Digges), $2 \mathrm{~g}$ (Coats, 1992) and $8 \mathrm{~g}$ (Coats, 1993). Samples were treated with cold base, hot acid and distilled water rinses. Dates were obtained by conventional radiocarbon analysis (R. McNeely, pers. comm. 1993). All dates are given \pm 2 standard errors. 


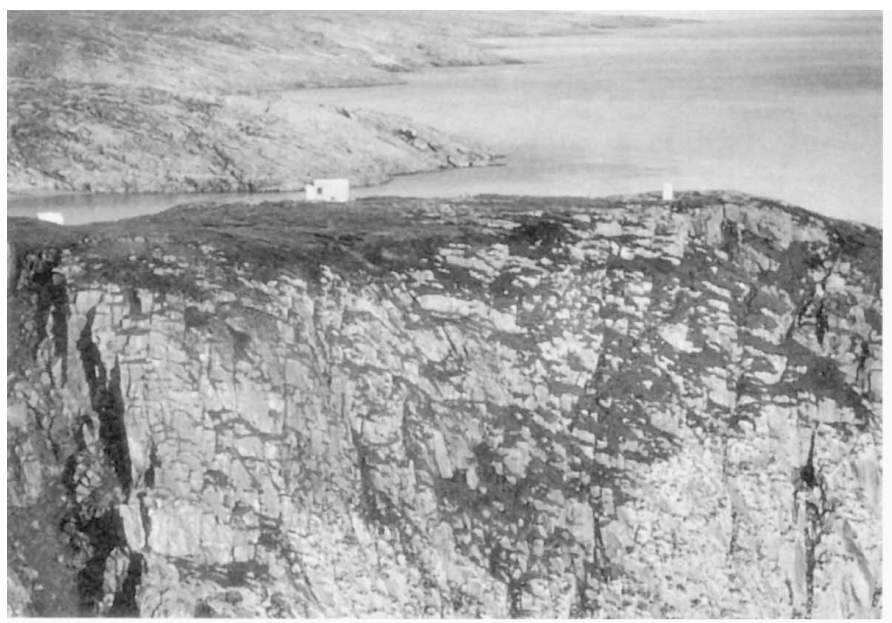

FIG. 2. Sampling location at Coats Island. Note the barren headlands in the distance, without any peat formation.

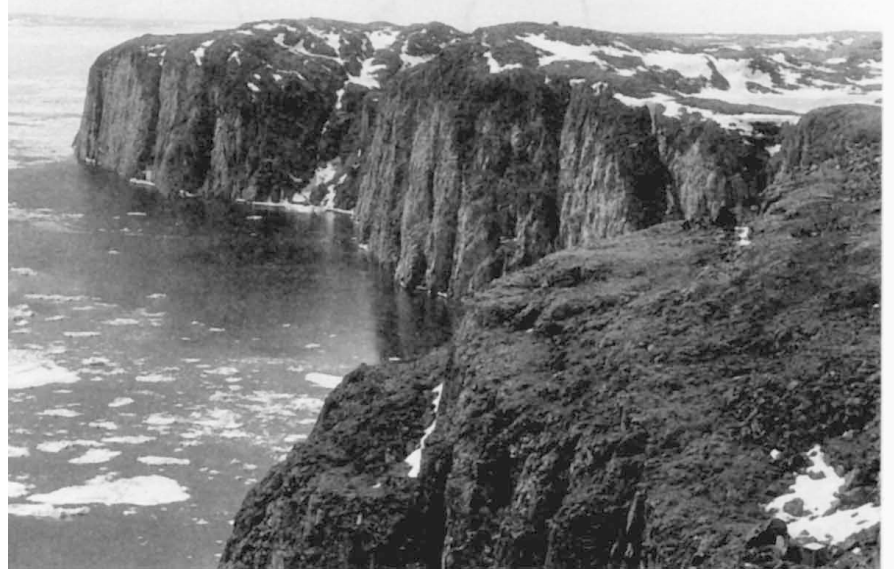

FIG. 3. Sampling location at East Digges Island. Note the extensive peat development in the foreground.

\section{RESULTS}

At all three colonies, peat was present along the entire length of the occupied cliffs. At Akpatok Island, peat was best developed in the centre of the North Colony, around the NE tip, known as Hell Cliff (Polunin, 1932), where the numbers of breeding birds also reach their highest density. Peat deposits and almost all vegetation stopped abruptly at the lateral limits of the colony (Fig. 4). At East Digges Island, peat was especially well developed in the centre of the colony. It was not found along the south or north coasts of the island, both of which are of similar elevation and geology to those of the murre colony area. Similar peat deposits were found on adjacent mainland coasts, where they were also closely associated with an extensive thick-billed murre breeding area. At Coats Island, peat was present at both sub-colonies, but absent from the intervening coast and from similar rocky headlands surveyed up to $10 \mathrm{~km}$ along the coast in either direction.

Inspection of the peat sections from which the radiocarbon dating samples were obtained showed no evidence of

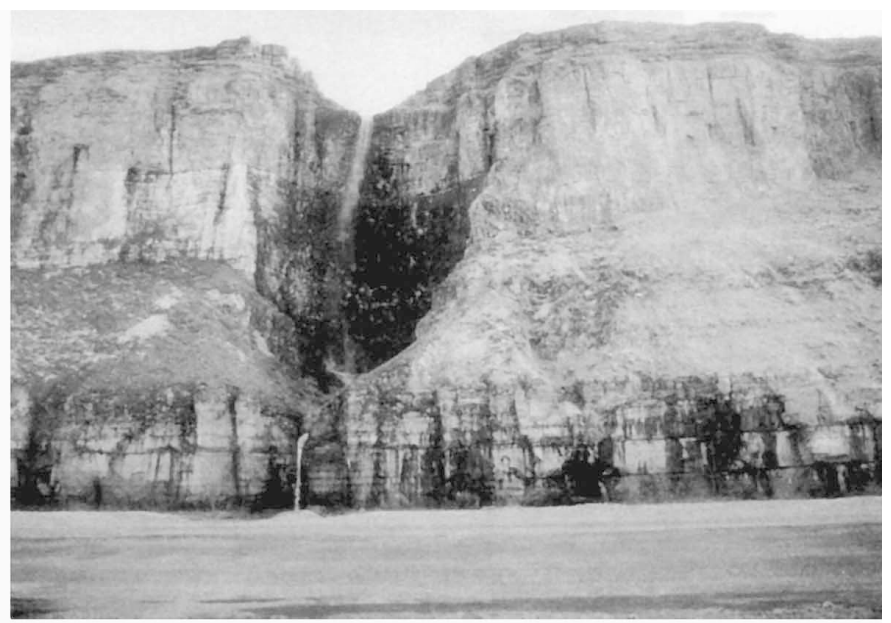

FIG. 4. The eastern edge of the northern thick-billed murre colony at Akpatok Island. Note the dense vegetation to the left of the ravine and the bare slopes to the right. The colony ends at the ravine.

discontinuities; the peat appeared uniform throughout. At East Digges Island, there was a little sand and gravel mixed into the base of the peat. The possibility that peat was eroded to bedrock at some time and then reformed at the site cannot be excluded.

Age determinations are given in Table 1. The 1992 and 1993 samples from Coats Island were obtained from the same excavation and the same level and the fact that their confidence intervals overlap confirms that the estimates are reproducible. As the level from which they were taken does not represent the bottom of the section, these dates can only be regarded as a minimum age for the peat. However, inspection of the local topography suggested that the level from which the samples came should represent more than $75 \%$ of the total depth of peat. Comparison of ages and depths of samples from the three colonies suggests a remarkably uniform rate of accumulation of peat (Fig. $5, \mathrm{R}^{2}=0.95, p<.05$ ) of about $1 \mathrm{~m}$ every 1789 years.

Analysis of the Coats Island pollen samples confirmed that the peat section consisted almost entirely of Dicranum, with scattered bakeapple leaves throughout. There was no suggestion from the embedded pollen of any change in local vegetation over the period represented (A.M. Davis, pers. comm. 1993).

\section{DISCUSSION}

Our observations confirm previous suggestions of a strong association between breeding colonies of thick-billed murres and the distribution of peat moss deposits in the Hudson Strait and northern Hudson Bay region. Various peat formations occur in lowland tundra areas, especially those waterlogged in summer (Love and Love, 1974). However, rocky uplands-especially those on limestone bedrock-rarely support peatlands. Probably, these peat deposits develop because of the manuring effect of seabird excreta and abandoned food remains, which are transported up the cliff by strong updraughts 
TABLE 1. Radiocarbon age determinations for samples of peat from three thick-billed murre colonies.

\begin{tabular}{lcc}
\hline \hline Colony & Depth $(\mathrm{m})$ & Radiocarbon Date +2 SE \\
\hline Akpatok Island & 2.0 & $3760 \pm 60$ \\
East Digges Island & 0.7 & $1560 \pm 60$ \\
Coats Island, 1992 & 1.3 & $2160 \pm 120$ \\
Coats Island, 1993 & 1.3 & $2070 \pm 60$ \\
\hline \hline
\end{tabular}

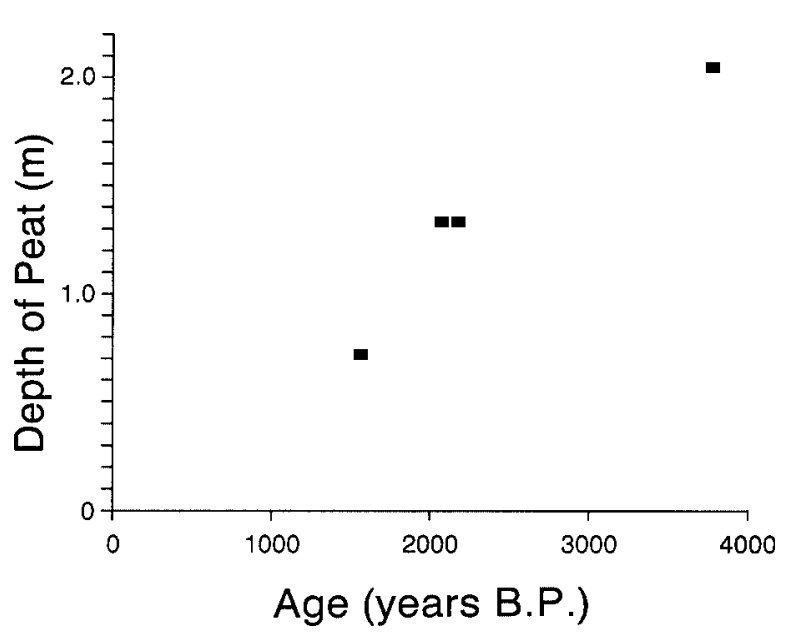

FIG. 5. Age-depth relationship for peat samples dated.

when the wind is blowing towards the land (thick-billed murres very rarely fly over land). Vertical wind speeds measured at the cliff face at Coats Island reached gusts of 80-100 km h ${ }^{-1}$ (G. Gilchrist, pers. comm. 1994). We frequently observed fragments of dried excreta and food remains up to $100 \mathrm{~m}$ inland from the colony cliffs.

The dominance of the moss Dicranum groenlandicum in the formation of peat in this area is surprising, as it is otherwise associated mainly with bogs, the margins of ponds and lakes and other perennially wet areas (R.R. Ireland, pers. comm. 1993). Although the areas of peat associated with the murre colonies are wet in places, the peat extends to welldrained areas on slopes as much as $20^{\circ}$ from the horizontal. At Akpatok Island, especially, the ground is very well drained, and surrounding areas are virtually devoid of vegetation.

The earlier initiation of peat formation at Akpatok Island, compared to the two colonies farther west, suggests that this colony was established much before the other two. This is in keeping with the idea that, being entirely marine in their distribution, and never flying over land except during exceptional weather conditions, thick-billed murres must have colonized Hudson Strait from the Labrador Sea, to the east. The dates of establishment of the two western colonies appear to be similar; however, the earlier date for Coats Islanditself only a minimum age - is surprising, because Digges Island is a much larger colony (180 000 breeding pairs vs. 30000 at Coats Island, Gaston et al., 1993) and is situated farther to the east. It is possible that the peat sampled at Digges Island did not represent the earliest laid down in the area.

All of the dates obtained are much later than the deglaciation of the Hudson Strait region, which began about 9000 B.P. and was probably completed by 7000 B.P. (Andrews, 1989). The apparent delay of several thousand years before thick-billed murres became established at their present sites indicates either that the birds are very conservative in their breeding habits, or that ecological conditions in Hudson Strait did not become suitable for thick-billed murres until long after deglaciation. Considering that small colonies of thick-billed murres have been founded in Greenland during the past 50 years, it seems unlikely that conservatism can explain the long delay in colonization. The apparent delay of more than a thousand years between the occupation of Akpatok Island and the establishment of the colonies at Digges and Coats Islands, may indicate that it took some time after the establishment of suitable conditions in eastern Hudson Strait for such conditions to extend as far west as Digges and Coats Islands. We also need to consider that it would have taken some time for the founding population to grow large enough for its manuring to initiate the development of peat. Likewise, conditions at the cliff top may not have been suitable initially for peat formation. No such peat has developed at Canadian High Arctic colonies (Prince Leopold Island, Cape Hay, Bylot Island). The dates obtained can give only a minimum age for the colonies.

At Coats Island, where the occupied area of the cliffs has a maximum elevation of $60 \mathrm{~m}$ and where marine terraces occur up to at least $90 \mathrm{~m}$ above the present sea level, the availability of breeding habitat may have been influenced by post-glacial sea level. The post-glacial emergence curve for Southampton Island suggests that sea levels were $50 \mathrm{~m}$ above present levels about 4000 B.P. and $20 \mathrm{~m}$ above present levels at 2000 B.P. (Dredge and Cowan, 1989). All present-day thick-billed murre colonies in the eastern Canadian Arctic are on cliffs as high or higher than those presently occupied at Coats Island. Consequently, the timing of colonization of Coats Island may have depended on the emergence of a suitable height of cliff.

Depths of peat recorded, especially the $2 \mathrm{~m}$ depth at Akpatok Island, are greater than usual for Arctic peat deposits (Nichols, 1974) and indicate that peat production was relatively rapid. The extreme uniformity of the sections at Coats and Digges Islands, and the fact that no change in local vegetation was apparent from the palynological investigations, suggest that the peat was laid down without a break. This presumably indicates that those two murre colonies have existed in their present locations more or less continuously for more than 1500 years.

\section{REFERENCES}

ANDREWS, R.J. 1989. Quaternary geology of the northeastern Canadian Shield. In: Fulton, R.J., ed. Quaternary geology of Canada and Greenland. Geological Survey of Canada, Geology of Canada, No. 1. 276-301.

CHAPDELAINE, G., GASTON, A.J., and BROUSSEAU, P. 1986. Censusing the thick-billed murre colonies of Akpatok Island, NWT. Canadian Wildlife Service Progress Note No. 163. 9 p. 
DELARUE, D. 1988. The vascular flora and vegetation of Île de Croy, Îles Kerguelen. Polar Record 24:111-118.

DREDGE, L., and COWAN, W.R. 1989. Quaternary geology of the southwestern Canadian Shield. In: Fulton, R.J., ed. Quaternary geology of Canada and Greenland. Geological Survey of Canada, Geology of Canada, No. 1. 214-249.

GASTON, A.J., CAIRNS, D.K., ELLIOT, R.D., and NOBLE, D.G. 1985. A natural history of Digges Sound. Canadian Wildlife Service Report Series No. 46. 66 p.

GASTON, A.J., ELLIOT, R.D., and NOBLE, D.G. 1987. Studies of thick-billed murres on Coats Island, Northwest Territories in 1981, 1984, 1985 and 1986. Canadian Wildlife Service Progress Note No. 167. 11 p.

GASTON, A.J., DE FOREST, L.N., GILCHRIST, G., and NETTLESHIP, D.N. 1993. Monitoring thick-billed murre populations at colonies in northern Hudson Bay, 1972-92. Canadian Wildlife Service Occasional Paper No. 80. 16 p.

GILLHAM, M. 1956. The ecology of the Pembrokeshire islands. V. Manuring by the colonial seabirds and mammals with a note on seed distribution by gulls. Journal of Ecology 44:428-454.

HENTZEL, I.R. 1993. Akpatok Island revisited. Environmental Conservation 19:361-363.

IASON, G.R., DUCK, C.D., and CLUTTON-BROCK, T.H. 1986. Grazing and reproductive success of red deer: The effect of local enrichment by gull colonies. Journal of Animal Ecology 55:507-515.
LOVE, A., and LOVE, D. 1974. Origins and evolution of the arctic and alpine floras. In: Ives, J.D., and Barry, R.G., eds. Arctic and alpine environments. London: Methuen. 571-603.

MIZUTANI, H., KABAYA, Y., and WADA, E. 1991a. Linear correlation between latitude and soil ${ }^{15} \mathrm{~N}$ enrichment at seabird rookeries. Naturwissenschaften 78:34-36.

MIZUTANI, H., KABAYA, Y., MOORS, P.J., SPEIR, T.W., and LYON, G.L. 1991b. Nitrogen isotope ratios identify deserted seabird colonies. Auk 108:960-964.

MOORS, P.J., SPEIR, T.W., and LYON, G.L. 1988. Soil analyses and ${ }^{13} \mathrm{C} /{ }^{12} \mathrm{C}$ ratios identify sites of deserted rockhopper penguin colonies. Auk 105:796-799.

NICHOLS, H. 1974. Arctic North American palaeoecology: The recent history of vegetation and climate deduced from pollen analysis. In: Ives, J.D., and Barry, R.G., eds. Arctic and alpine environments. London: Methuen. 637-667.

POLUNIN, N. 1932. The isle of auks. London: Edward Arnold. $253 \mathrm{p}$.

SCHAU, M. 1991. Orthogneisses, paragneisses and high strain zones on northeast Coats Island, District of Keewatin, N.W.T. In: Current Research, Part C, Geological Survey of Canada, Paper 91-1C. 195-205.

SMITH, V.R. 1978. A qualitative description of energy flow and nutrient cycling in the Marion Island terrestrial ecosystem. Polar Record 18:361-370.

STEMPNIEWICZ, L. 1990. Biomass of dovekie excreta in the vicinity of a breeding colony. Colonial Waterbirds 13:62-66. 